\title{
Medial meniscus transplantation using cyanoacrylate in rabbits ${ }^{1}$
}

\author{
Transplante de menisco medial utilizando cianoacrilato em coelhos
}

\author{
Leandro José Reckers², Djalma José Fagundes ${ }^{3}$, Moisés Cohen ${ }^{4}$ José Luiz Pozo Raymundo ${ }^{5}$, Márcia Bento Moreira ${ }^{6}$, \\ Vanessa Carla Paiva ${ }^{6}$ \\ 1. Research from Surgery and Experimentation Post-Graduate Program of São Paulo Federal University/Escola Paulista de Medicina - São \\ Paulo, Brazil. \\ 2. PhD - Department of Orthopedics, Pelotas Catholic University - Rio Grande do Sul,-Brazil. \\ 3. PhD - Department of Surgery, São Paulo Federal University - São Paulo, Brazil. \\ 4. PhD - Department of Orthopedics, São Paulo Federal University - São Paulo, Brazil. \\ 5. PhD - Department of Orthopedics, Pelotas Federal University -Rio Grande do Sul, Brazil. \\ 6. Veterinary from Surgery and Experimentation Post-Graduate Program of São Paulo Federal University- São Paulo, Brazil.
}

\begin{abstract}
Purpose: To evaluate meniscal transplantation using as fixation method a synthetic glue derived from cyanoacrylate acid. Methods: Twenty rabbits were used, of which 10 for autologous transplantation and 10 for homologous transplantation. For the autologous transplantation the meniscus was removed, and then transplanted in the same animal, using the synthetic glue. For the homologous transplantation, the study was divided into two stages: 1- Removal of the meniscus which was maintained at a temperature of $73^{\circ} \mathrm{C}$. 2- Use of cyanoacrylate acid-derived surgical adhesive for meniscal retransplantation in a different rabbit 30 days after the transplant. Results: Due to complications, euthanasia had to be anticipated to the $15^{\text {th }}$ day in the homologous group and to the $18^{\text {th }}$ day in the autologous group. Macroscopically, knees submitted to transplantation presented whitish secretions from the surgical incision up to deep planes. Necrosis was observed in both groups. Statistical analysis has shown that mild $(\mathrm{p}=0.043)$ and moderate $(\mathrm{p}=0.001)$ complications emerged in a significantly earlier way in the homologous group, where euthanasia was also performed earlier $(\mathrm{p}=0,005)$. Conclusion: Synthetic surgical adhesives derived from cyanoacrylate acid promoted cortical to medullary bone necrosis bone in both groups.
\end{abstract}

Key words: Menisci, Tibial. Transplantation. Cyanoacrylates. Rabbits.

\section{RESUMO}

Objetivo: Avaliar macroscópica e histologicamente o transplante meniscal, utilizando-se a cola sintética derivada do ácido cianoacrilato como método de fixação. Métodos: Foram utilizados 20 coelhos, tendo 10 realizado transplante autólogo e 10, homólogo. Para o transplante autólogo, o menisco foi retirado e em seguida transplantado no mesmo animal, sendo fixado com a cola sintética. Para o transplante homólogo o estudo foi dividido em duas etapas: 1- retirada do menisco e manutenção a uma temperatura de $73^{\circ} \mathrm{C}$ negativos. 2- Utilização do adesivo cirúrgico derivado do ácido cianoacrilato para reimplantar num coelho diferente 30 dias após o congelamento. Resultados: Devido às complicações foi necessário antecipar as eutanásias para o $15^{\circ}$ dia do grupo homólogo e $18^{\circ}$ para o grupo autólogo. Macroscopicamente, os joelhos submetidos aos transplantes apresentavam secreções esbranquiçadas desde a incisão cirúrgica até planos profundos. Histologicamente, necrose estava presente em ambos os grupos. A análise estatística mostrou que as complicações leves ( $p=0,043)$ e moderadas ( $\mathrm{p}=0,001)$ surgiram de forma significantemente mais precoce no grupo homólogo, sendo, também, a eutanásia realizada mais precocemente neste grupo $(\mathrm{p}=0,005)$. Conclusão: Os adesivos cirúrgicos sintéticos, derivados do ácido cianoacrilato, provocaram necrose desde a cortical até a medular óssea para ambos os grupos.

Descritores: Meniscos Tibiais. Transplante. Cianoacrilatos. Coelhos.

\section{Introduction}

The meniscus plays several roles contributing to knee function. Many clinical studies have documented the detrimental effects of loss of meniscus function. Traumatic meniscal injury, with or without meniscectomy, modifies forces crossing the knee, exacerbating articular cartilage degeneration and developing early osteoarthritis ${ }^{1-7}$. Meniscal transplantation has been recommended for selected meniscus-deficient patients in an effort to forestall progressive joint degeneration ${ }^{8,9}$. Early results of meniscal transplantation indicate predictable improvements in pain, swelling and knee function. Some long-term studies of meniscal transplantation have proven that cartilage protection is possible. So meniscal transplantation emerges as a useful option for selected patients with stable knee 
and appropriate alignment ${ }^{10-13}$. Current surgical procedures for meniscus fixation are sutures, screw, bone bridge technique or bone block ${ }^{11-15}$. Fibrin glue adhesive has been used in one pilot study in $1995^{(16)}$ and there is no reference to cyanoacrylate. This research aimed at determining the efficacy of synthetic glue for meniscus fixation, based on the successful use of cyanoacrylate in other surgical areas ${ }^{17-}$ ${ }^{22}$ which have shown its strong adhesive capacity.

\section{Methods}

Twenty New Zealand rabbits, six months old, weighing 2,5Kg, coming from CEDEME (Development Center of Experimental Animals Models for Biology and MedicineFederal University of São Paulo-Brazil), with Ethics Committee Protocols number 1010/04, were randomized in two groups $(n=10)$. All procedures were done in the laboratories of Experimental Surgery of Surgical DepartmentUNIFESP-EPM.

\section{Anesthetic procedure}

After six hours fasting for solid diet and four hours for liquid diet, animals received acepromazin ( $5 \mathrm{mg} / \mathrm{Kg}$ ) IM and, ten minutes later, an association of ketamin $(50 \mathrm{mg} / \mathrm{Kg})$ and xylazin $(10 \mathrm{mg} / \mathrm{Kg}) \mathrm{IM}$. Anesthesia was maintained with oxygen and $2.5 \%$ isoflurane.

\section{Surgical procedure}

Group A $(n=10)$ : The autologous transplantation group (AT) was submitted to parapatellar longitudinal medial incision dissecting subcutaneous tissue with lateral patellar luxation, articular capsule exposure and removal of right knee medial menicus. Autologous transplantation of right knee medial meniscus was performed immediately after in the same place with cyanoacrylate. Skin and subcutaneous tissue were sutured with nylon 4.0 interrupted suture.

Group H ( $n=10)$ : In the homologous group (HT), right knee medial meniscus was transplanted in different rabbits after deep freezing $\left(-73^{\circ} \mathrm{C}\right)$ for thirty days. For the meniscus fixation the specimen was softly dried throughout with gauze. Two cyanoacrylate drops $(0,1 \mathrm{ml})$ were applied to both surfaces and carefully maintained in the articular surface of the receptor knee for two minutes. In the immediately post-operative period and for the first 48 hours all animals received a daily dose of an association of benzatin penicillin $(600,000 \mathrm{UI})$, dihidroestreptomicin (250mg) and procain (300,000UI), enrofloaxin (5mg/Kg) and tramadol (5mg/Kg).

\section{Frozen meniscus procedure}

The meniscus was measured and washed in saline solution ( $\mathrm{NaCl} 0.9 \%)$, and stored in a sterile plastic bag under deep freezing $\left(-73^{\circ} \mathrm{C}\right)$ until the transplantation day. In day thirty the bag with the meniscus was washed in saline solution for twenty minutes, at neutral temperature, for defrost. Removed from the bag and cleaned in different saline solution, the meniscus was transplanted to a different rabbit's right knee.

\section{Follow-up and morphological features}

Healing was observed daily. Parameters recorded were: edema, pain, fever, diet refusal, lack of active movement outside the cage and passive test mobilization (extension) of the operated knee. All signs/symptoms were recorded as mild (score $=1$ ), moderate (score $=2$ ) or severe (score $=3$ ). The transversal distance of distal tibia of operated knee and of the ipsilateral knee was measured with a pachymeter. Edema was evaluated by the ratio: [(operated knee) - (non operated knee) x 10]. Pain was evaluated by soft tissue compression, with the pachymeter at $1.5 \mathrm{~cm}, 1.0 \mathrm{~cm}$ and $0.5 \mathrm{~cm}$ according to edema size, and which could produce some painful stimulation. The sum of the daily scores was plotted in a histogram for each animal versus the observation day. Sum was considered mild when score was 6 , moderate when score was 12 and severe when score was 18 (Table 1 ).

Follow-up was previously established as sixty postoperative days. Due to some unexpected events shown on results the observation period was shortened. Suture dehiscence with caseous secretion appeared within two to three postoperative weeks. Samples were collected for culture and antibiogram.

TABLE 1 - Parameters and respective scores used for daily healing evaluation

\begin{tabular}{llll}
\hline Parameters & $\begin{array}{l}\text { Mild } \\
\text { Score 1 }\end{array}$ & $\begin{array}{l}\text { Moderate } \\
\text { Score 2 }\end{array}$ & $\begin{array}{l}\text { Severe } \\
\text { Score 3 }\end{array}$ \\
\hline Edema (Operated knee) - (non operated knee) $\mathbf{x} \mathbf{1 0}$ & Ratio $=0-30$ & Ratio = 31-60 & Ratio $>61$ \\
\hline Pain (Pachymeter compression and muscular reaction) & $1.5 \mathrm{~cm}$ & $1.0 \mathrm{~cm}$ & $0.5 \mathrm{~cm}$ \\
\hline Fever (Rectal temperature) & $+10 \mathrm{C}$ & $+1.5-2 \mathrm{OC}$ & $>2 \mathrm{CC}$ \\
\hline Diet refusal (Percentage of diet weight) & $0-10 \%$ & $11-30 \%$ & $>31 \%$ \\
\hline Active movement & $100-50 \mathrm{~cm}$ & $49-20 \mathrm{~cm}$ & $19 \mathrm{~cm}$ or not \\
Outside the cage & walk & walk & walk \\
\hline $\begin{array}{l}\text { Passive test movement } \\
\text { (knee extension angle) }\end{array}$ & $10-20 \%$ & $21-30 \%$ & $>31 \%$ \\
\hline Total & Restriction & Restriction & Restriction \\
\hline
\end{tabular}




\section{Meniscectomy and histological samples}

Under anesthesia and in an adequate day, meniscus was removed and all biological events were described and recorded by a digital camera. For light microscopy, meniscus and tibial plateau specimens were fixed in $10 \%$ formalin, soaked in paraffin, and stained with hematoxilin-eosin (HE). The morphometric evaluation consisted of quantitative cell analysis to check inflammatory and soft-tissue reaction. Measured parameters were inflammatory infiltrate [partial volume (PV) or \%], connective tissue (PV\%), macrophages(\%), fibroblast(\%) and fibrocondrocytes(\%).

\section{Euthanasia}

Animals were sacrificed according to the severity of complications. Under anesthesia, animals received an association of intravenous embutamide, mebezone and tetracain $(0.1 \mathrm{mg} / \mathrm{Kg})$ with has promoted rapid and painless death (Table 1).

\section{Results}

The sum of signals/symptoms was considered mild when reaching score 6 , moderate when reaching 12 and severe when reaching 18 both for the AT (Figure1) and HT (Figure 2) groups. Earlier and most important signal was the edema which appeared first around the incision and then spread along the thigh. The loss of active movements inside (and outside) the cage and the limitation of passive movements were, in order, the last to be observed. Rectal temperature increased 24/36 hours before the presence of secretions. Caseous secretion appeared in a couple days immediately after the maximum score. When spontaneous caseous secretion appeared from the surgical scar, the observation period was interrupted and animals were sacrificed. We plotted this as final event. Mild (AT mean=5.8 / HT mean =5.8), moderate (AT mean=9.0 / HT mean =9.0) and severe (AT mean=14.3 / HT mean =13.3) scores were seen in both groups. In TA group, macroscopic findings scores peaked around day 14 with the presence of thicker caseous secretion through the surgical scar and animals were sacrificed. On TH group, similar findings were seen around the $13^{\text {th }}$ postoperative day. Tissues around the incision (articular cartilage, articular capsule, extensor muscles, subcutaneous tissue and skin) were infiltrated by the caseous secretion with consequent necrosis (Figure 3). After removing the white and gelatinous secretion and prolonging incision dehiscence we could see the necrosis of transplanted meniscus and the erosion of the tibial plateau (Figure 4). Menisci of all animals were free in the articular cavity and, due to severe damage, they were smaller, dark and brittle. Tissue reactions to cyanoacrylate glue were severe and showed no significant differences in caseous secretion and bone erosion between AT (caseous 80\% erosion 40\%) and HT (caseous 90\% - erosion 50\%) groups. Morphometric analysis of inflammatory cells percentage has shown similar macrophages for both groups. The percentage of fibroblasts and fibrochondrocytes was minimal in the homologous group due to deep frozen storage.

No bacterial growth was seen in the cultures.

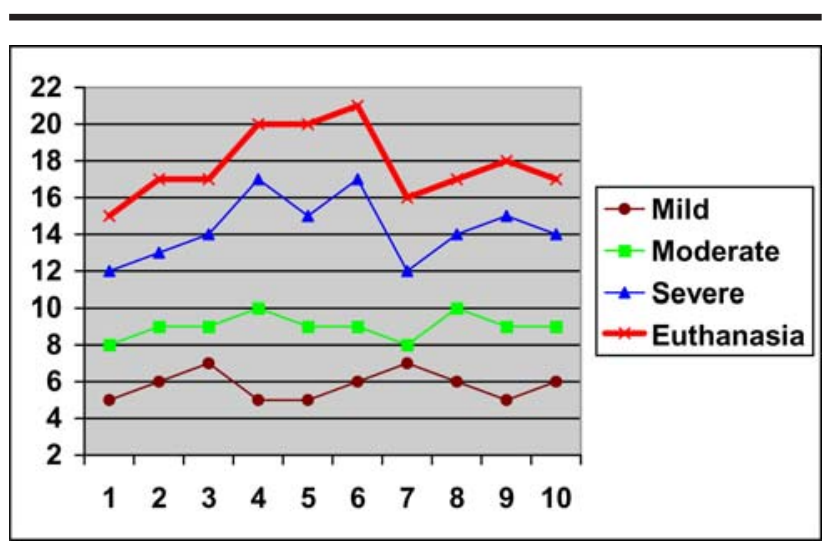

FIGURE 1 - Animals of autologous group with the sum of signals/symptoms plotted when they reached score 6 (mild), score 12 (moderate) and score 18 (severe). Euthanasia day corresponded to the presence of caseous secretion in the surgical scar.

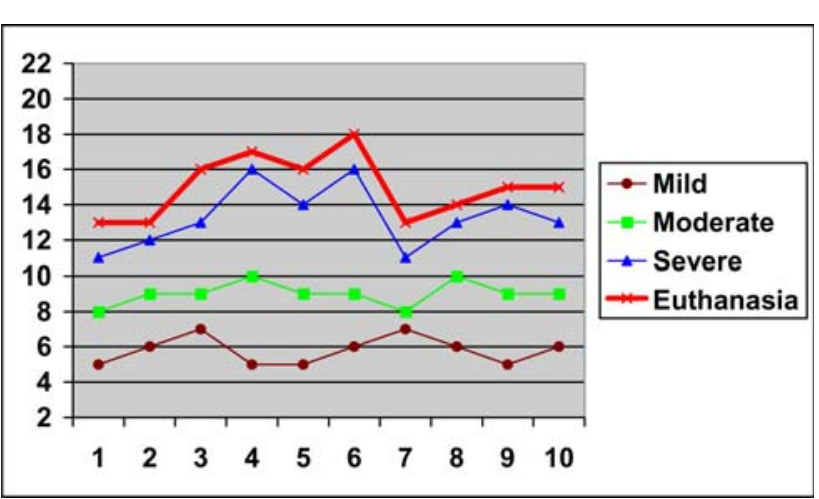

FIGURE 2 - Animals of homologous group with the sum of signals/symptoms plotted when they reached score 6 (mild), score 12 (moderate) and score 18 (severe). Euthanasia day corresponded to the presence of caseous secretion in the surgical scar.

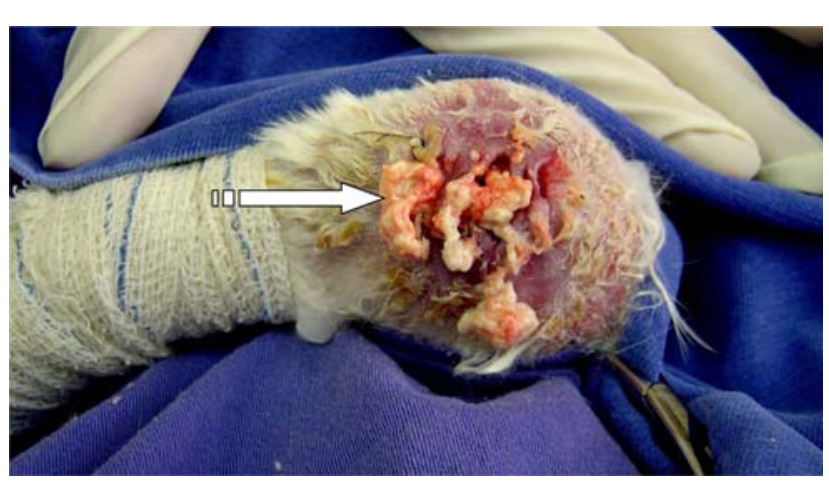

FIGURE 3 - Aspect of the surgical scar with edema, skin hyperemia and caseous secretion (arrow). 


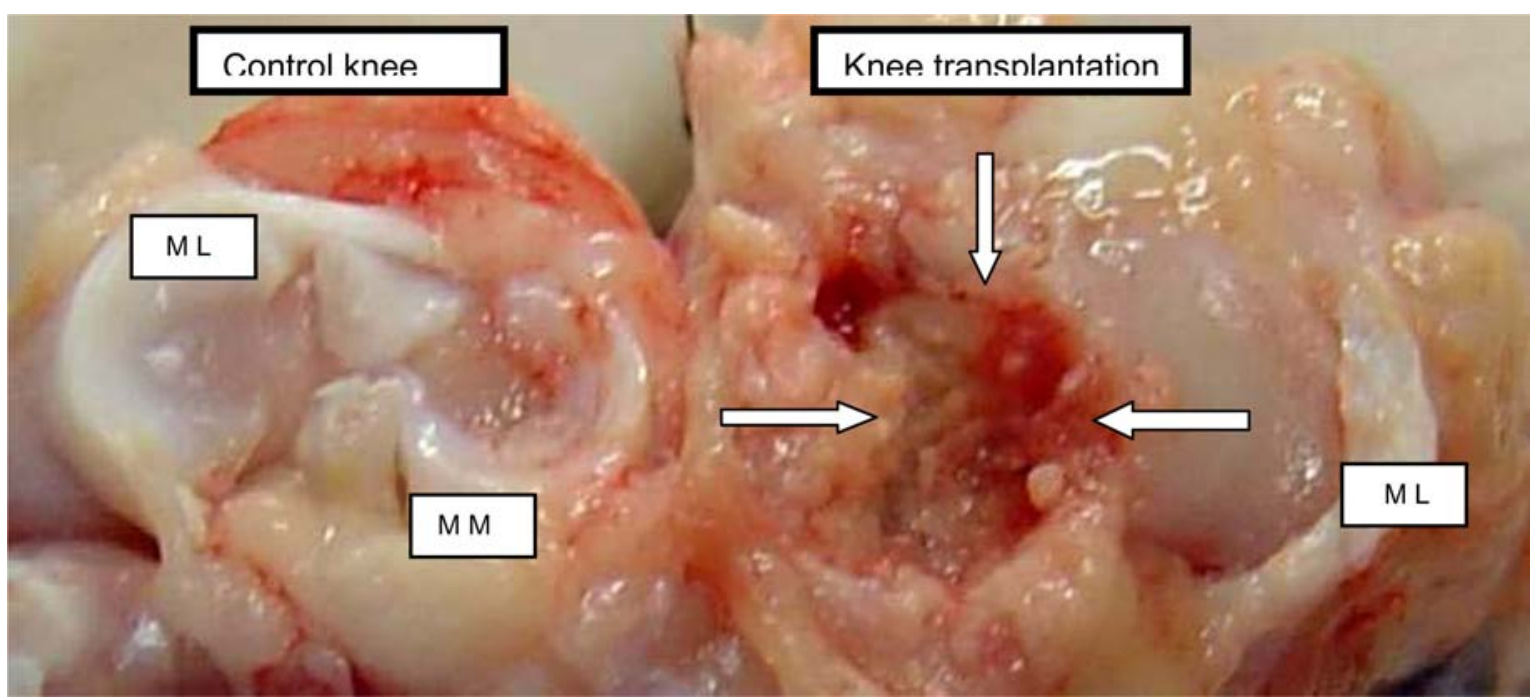

FIGURE 4 - Tibia plateau erosion (arrow) after removal of necrotic meniscus. Homologous group: Left side: control knee. Right side: transplanted meniscus. LM - lateral meniscus MM - medial meniscus.

\section{Discussion}

As we enter the new century, it becomes evident that a brand new era lies ahead for meniscal repair or transplantation, and the journey promises to be very exciting ${ }^{23}$. To accomplish this objective it will involve the use of adhesive materials, possibly autologous but more probably exogenous, supported by the insertion of a collagenous-type material, which will scaffold the in growth of fibrocartilage. Animal studies have documented that meniscal allografts can heal in the recipient. Techniques for the fixation of transplanted menisci using meniscal horn fixation and bone block fixation have been described. Several biomechanic studies have shown considerable improvement of tibial surface mechanical contacts, both with meniscal horn and bone block fixation ${ }^{12,14}$. Surgical glue may be a proposal for faster and safer meniscal fixation. In our study, synthetic adhesive fixation was considered excellent, straight after its use, keeping the menisci with adequate stability for flexion and extension movements of the knee during the procedure. Nabeshima et al. ${ }^{16}$ have transplanted dogs' deep-frozen meniscal allograft with suture or fibrin glue and concluded that there was no difference between both groups at 12 weeks ${ }^{16}$. However, there is no reference to cyanoacrylate. Cyanoacrylate glues are biodegradable, bacteriostatic, hemostatic adhesives which have been used experimentally in surgical procedures on many tissues. Our hypothesis was that a local adhesive might improve fixation of meniscus transplantation ${ }^{24}$. However, there were considerable clinic complications, like edema, bone erosion and severe caseous secretion, which was earlier for the homologous group and later for the autologous group (Figures 1 and 2), and has compromised the success of the transplants (Figures 3 and 4). The exothermic chemical reaction of cyanoacrylate polymerization, although promoting firm and stable fixation immediately after application, may have also promoted tissue necrosis and consequent inflammatory response in both groups. Both studied groups reached scores equal to or above 18 for presented symptoms, with earlier symptoms for the homologous group as compared to the autologous groups. This may be justified, perhaps, by the graft versus host immune reaction, which may, in a way, have boosted the exothermic reaction of that group, inducing an earlier reaction. However, there were no differences in symptoms between autologous and homologous groups, suggesting that the synthetic surgical adhesive could have acted as foreign body in both groups. Both groups were similar in inflammatory infiltrate characteristics. However, in terms of fibroblasts and fibrochondrocytes, the fact of being less in the homologous group reflects the already proven cell death promoted by freezing promotes after the storage of these menisci. Lastly, the presence of sterile cultures on collected secretions is a further support to the fact that such reactions were really triggered by the presence of the surgical adhesive derived from cyanoacrylate acid. The findings of our study, to date not reported in the literature, indicate that the use of adhesives as fixation method for meniscus transplantation has to be object of further studies to confirm our results.

\section{Conclusion}

Surgical adhesives derived from cyanoacrylate acid used for the fixation of transplanted menisci have promoted necrosis from the cortex to the bone marrow of transplanted bone surface.

\section{References}

1. Fukubayashi T, Kurosawa H. The contact area and pressure distribution pattern of the knee: a study of normal and osteoarthrotic knee joints. Acta Orthop Scand. 1980;52:871-9.

2. King $D$. The healing of semilunar cartilages. J Bone Joint Surg. 1936;18:333-42. 
3. Fairbank TJ. Knee joint changes after meniscectomy. J Bone Joint Surg Am. 1948;30(4):664-70.

4. Aagaard H. Reduced degenerative articular cartilage changes after meniscal allograft transplantation in sheep. Knee Surg Sports Traumatol Arthroscopy. 1999;184-91.

5. Jaureguito JW, Eliot J, Lietner T, Dixon LB, Reider B. The effects of arthroscopic partial meniscectomy in a otherwise normal knee: a retrospective review of functional, clinical and radiographic results. Arthroscopy. 1995;11:29-36.

6. Milachowski KA, Weismeier K, Wirth CJ. Homologous meniscus transplantation: Experimental and clinical results. Int Orthop. 1989;13:1-11.

7. Jones RE, Smith EC, Reisch JS. Effects of medial meniscectomy in patients older than forty years. J Bone Joint Surg Am. 1978;60:783-6.

8. Rodeo SA. Meniscal allografts. Where do we stand? Am J Sports Med. 2001;29:246-61.

9. Friedman MD. Meniscal allografts. Arthroscopy. 2003:18:33-9.

10.Peters G, Wirth CJ. The current state of meniscal allograft transplantation and replacement. Knee. 2003;10:19-31.

11.Graf Jr, KW, Sekiya JK, Wojtys EM. Long-term results after combined medial meniscal allograft transplantation and anterior cruciate ligament reconstruction: minimum 8,5 year follow-up study. Arthroscopy. 2004;20(2):129-40.

12.Ellingson CI, Sekija JK. Current opinion in meniscal allograft transplantation. Curr Opin Orthop. 2004;15(2):79-85.

13.Felix NA, Paulos LE. Current status of meniscal transplantation. Knee. 2003;10:13-7.

14.Farr J, Meneghini RM, Cole BJ. Allograft interference screw fixation in meniscus transplantation. Arthroscopy. 2004;20(3):322-7.

15. Yoldas EA, Sekija JK, Irrgang JJ, Fu FH, Harner CD.
Arthroscopically assisted meniscal allograft transplantation with and without combined anterior cruciate ligament reconstruction. Knee Surg Sports Traumatol Arthroscopy. 2003;11(3):173-82.

16. Nabeshima Y, Kurosaka M, Yoshiya S, Mizuno K. Effect of fibrin glue and endotelial cell growth factor on the early healing response of the transplanted allogenic meniscus: a pilot study. Knee Surg Sports Traumatol Arthroscopy. 1995;3:34-8.

17.Sekine T, Nakamura T, Shimizu Y, Ueda H, Matsumoto K, Takimoto Y, Kiyotani T. A new type of surgical adhesive made from porcine collagen and polyglutamic acid. J Biomed Mater Res. 2001;54(2):305-10.

18.Ushakov AI, Bozhukov DA, Ushakova TM. The use of a cyanoacrylate based composite material in operations on the alveolar processes of the jaws. J Stomatol. 2000;79(1):17-9.

19.Perron AD, Garcia JA, Parker-hays E, Schafermeyer R. The efficacy of cyanoacrylate-derived surgical adhesive for use in the repair of lacerations during competitive athletics. Am J Emerg Med. 2000;18(3):261-3.

20.Lee Y, Chan F, Ng E, V Leung, Law K, Yung M, Chung S, Sung J. EUS-guided injection of cyanoacrylate for bleeding gastric varices. Gastrointest Endosc. 2000;52(2):168-74.

21.Pérez M, Fernández I, Márquez D, Bretaña RMG. Use of N-butyl-2-cyanoacrylate in oral surgery: biological and clinical evaluation. Artif Organs. 2000;24:241-3.

22. Gonzalez E, Orta J, Quero C, Niemshik L, Galera R, Onay D, Rojas O. Ethyl-2-cyanoacrylate fixation of the cranial bone flap after craniotomy. Surg Neurol. 2000;53(3):288-9.

23.Kollias SL, Fox JM. Meniscal repair. Where do we go from here? Clin Sports Med. 1996;15(3):621-30.

24.Koukoubis TD, Glisson RR, Feagin JA, Seaber AV, Vail TP. Augmentation of meniscal repairs with cyanoacrylate glue. J Biomed Mater Res. 1995;29(6):715-20.
Correspondence:

Leandro Reckers

Rua Almirante Barroso, 2249

96010-280 Pelotas - RS Brazil
Conflict of interest: none Financial source: none

Received: October 19, 2005

Review: November 17, 2005

Accepted: December 14, 2005

\section{How to cite this article:}

Reckers LJ, Fagundes DJ, Cohen M, Raymundo JLP, Moreira MB, Paiva VC. Medial meniscus transplantation using cyanoacrylate in rabbits. Acta Cir Bras. [serial on the Internet] 2006 Mar-Apr;21(2). Available from URL: http://www.scielo.br/acb 